\title{
IMAJINASI SEBAGAI ROH KREATIF INTELEK DALAM PROSES KREASI PENCIPTAAN KARYA SENI
}

banyak dibahas ulang sampai dasar, hingga pola-pola pemahaman konvensional yang masih mengandaikan kutub subjek-obyek atau mengandaikan penafsiran

\section{Susapto Murdow}

\section{Fakultas Bahasa dan Seni UNY}

\section{Abstract}

Many people write about art and works of art. The discussions about works of arts use new paradigms such as phenomenology, post-structuralism, semiotics as well as hermeneutics, to reveal the meanings of art and visual art. In the process of evaluating and analyzing works of art, some of the paradigms tend to pay no attention to the subject (the artist). This article is written to remind that an artist as the subject needs to be regarded as the centre of meanings as a whole, including the background that surrounds the art creating process.

\section{A. Pendahuluan}

Akhir-akhir ini banyak dijumpai aneka ragam karya dan kekaburan konsep karya seni rupa yang mengakibatkan pula banyak pemahaman tentang karya seni. Hal Ini menjadi wilayah yang membingungkan. Parameter-parameter klasik dalam karya seni rupa telah ikut digugat. Pada kenyataannya bahwa semakin hari makin sulit bagi orang untuk mengklaim dirinya sebagai seniman ataupun ahli seni rupa. Gejala pemahaman ini juga nampak pada sebagian mahasiswa kita. Ini semua ditandai dengan kecenderungan membuat karya yang mengesampingkan dan tidak menyukai persoalan teknik konvensional (lebih diskursif), ia menyukai media baru misalnya: Instalasi Art, Video Art, Public Art, bahkan Net Art. Mahasiswa sekarang mempunyai kecenderungan baru, yaitu semangat ingin cepat mandiri (kecenderungan berkarya sensasional- lebih figural) yang dipicu dan dipacu oleh Teknologi informasi yang bersifat serba cepat bahkan tanpa seleksi. Diskusi-diskusi seni selama ini selalu mengarah pada persoalan hakekat, Apakah seni hari ini? Apakah seni lukis ? Apakah Teknik itu? Apakah seni hanya begitu? Dimana fungsi sosial nya ? Sejauhmana peran sebuah gaya dan penting? dan seterusnya. Kalau sudah demikian, Bagaimana sikap kita sebagai pengampu? atau kurikulum yang diperluas bahkan dirubah ? Pertanyaan ini tidak serta merta dapat dijawab dengan mudah, tentu diperlukan refleksi agar arah jawaban menjadi jelas dan nyata.

Kebiasaan pemahaman karya seni sering dilihat hanya mengandung unsur deskripsi, analisis formal, interpretasi dan evaluasi, saat ini banyak orang cenderung berhenti di wilayah interpretasi. Konsep tentang interpretasi kini telah 
obyektivitas yang sebetulnya sudah menjadi problematis. Sebuah karya seni rupa dapat saja dilihat sebagai entitas konfigurasi simbolik yang menyiratkan banyak kemungkinan tafsiran tak terbatas dan lebih tidak terduga dari pada yang dikira penciptanya.

Kita mulai pengembaraan ini dengan pengertian yang mendasar. Istilah roh berasal (Latin: spiritus) sebenarnya bukan dipahami dalam arti yang sempit (sebagai suatu entitas mental tersendiri dalam diri manusia). Di sini roh diartikan secara lebih umum sebagai sesuatu yang menjiwai serta menggerakkan, sesuatu yang cenderung bersifat ilahi. Pemahaman baru yang hendak diungkapkan di sini adalah bahwa intelek sebenarnya tidak pernah berdiri sendiri terlepas dari imajinasi. Barangkali dapat dibandingkan dengan tubuh manusia yang tidak dapat berguna atau bergerak, tidak hidup, jika tanpa roh yang menjiwainya.

Selama ini kita lebih mudah mengatakan bahwa pemahaman serta pengetahuan itu diperoleh dari intelek atau akal budi. Namun penggambaran semacam ini sebenarnya merupakan pembatasan terhadap pengertian pengetahuan itu sendiri. Kalau pemahaman akan pengetahuan adalah seperti itu, maka pengetahuan itu dianggap senantiasa bersifat verbal, meskipun demikian yang verbal tidak selalu terbahasakan atau terkatakan. Pengetahuan intelektual dapat dikatakan verbal karena kaitan yang sangat erat antara intelek dan bahasa. Sedangkan fungsi intelek adalah mengangkat fenomena-fenomena ke dalam ide atau konsep yang lebih abstrak, maka dapat dipahami bahwa sudah terjadi semacam pem-bahasaan realitas atau fenomena tersebut. Implikasi lebih jauh adalah, bahwa intelek sebenarnya tergantung pada pengalaman. Meskipun sebagai suatu kemampuan inteligensial-abstraktif intelek tetap mempunya kelebihan yang orisinal dalam hal pembelajaran, yakni kecepatan memahami (kemampuan belajar), kedalaman pemahaman, dan kejelasan ekspresi. Intelek akan terus berkembang karena dapat dipelajari serta dikembangkan secara lebih sistematis dalam diri manusia. Unsur pembelajaran ini sebagai salah satu ciri penting intelek. Sebagaimana pandangan Eccles: bahwa imajinasi itu tidak dapat dipelajari. Imajinasi dalam bahasa tradisional, adalah suatu anugerah yang hanya dapat diterima. Oleh sebab itu, kini mulai tampak bagaimana imajinasi itu dapat dianalogikan dengan roh intelek. Sebagai suatu kemampuan yang dianugerahkan pada setiap pribadi, Imajinasi bagaikan roh dalam diri manusia yang juga dianugerahkan.

Kebingungan, bahkan kemandekan dalam bidang sains, fisika, kimia, biologi, seni dan teknologi kontemporer yang hendak ikut menciptakan makhlukmakhluk hidup identik dengan kehidupan, karena tanpa roh yang bersatu dengan badan berarti manusia tidak hidup lagi. Demikian juga dengan imajinasi sebagai suatu daya. Pada wilayah pikiran, daya-daya dalam diri manusia saling mempengaruhi serupa dengan keberadaan fisik maupun rohaninya. Kalau analogi ini diterapkan pada imajinasi dan intelek, maka akan terlihat bahwa intelek itu kendati dalam pengertian lain hanya berbeda fungsi dengan imajinasi- adalah kemampuan mengabstraksi yang hanya dapat dipicu dan dipacu oleh imajinasi. Kemampuan intelek kita, dapat dikatakan, dibangunkan dan dihidupkan oleh imajinasi, sehingga dapat menghasilkan abstraksi yang hidup pula. Sebuah konsep yang dihasilkan oleh intelek dapat berupa konsep, desain atau sebuah rumus karya seni tertentu, bahkan hanya berupa rumus saja. Akan tetapi, rumus itu justru menjadi dapat dipahami (intelligible) karena imajinasi kita yang menghidupkannya. Lebih jauh lagi dikatakan bahwa imajinasi kita dapat memunculkan variabel-variabel di dalam rumus tersebut, sehingga rumus tersebut menjadi tampak mungkin. Akhirnya, mesti diingat bahwa imajinasi sudah berperan jauh sebelum suatu rumus atau variabel di dalamnya terpikirkan, dengan tetap mempertahankan keilmiahannya, yakni dalam distansi dan pengimajian objek-objek ilmu yang sangat jauh ataupun yang sangat kecil.

Sekarang perlu diingat bahwa imajinasi itu bukan sekadar roh intelek, tetapi juga roh kreatif intelek. Pada pembicaraan sehari-hari kita cenderung mengatakan bahwa mahasiswa atau anak didik yang kreatif itu karena ia penuh dengan inisiatif, atau karena kuat daya imajinasinya. Kita tidak langsung mengatakan bahwa mahasiswa yang kreatif itu karena inteleknya kuat atau inteligensinya tinggi. Banyak contoh justru memperlihatkan bahwa mahasiswa yang inteligensinya tinggi tidak selalu kreatif, bahkan bisa jadi malah sangat tidak kreatif. Kecenderungan dan kenyataan seperti itu bukannya tanpa alasan, karena kreativitas itu muncul bukan karena seseorang itu pandai secara intelektual. Kreativitas muncul dan kuat tatkala seseorang membuka kemampuan imajinatifnya. Bersamaan dengan itu, bukan sekadar kreativitas yang muncul, tetapi-berbicara secara etis-inisiatif untuk bertindak menjadi lebih kuat. Dalam hal ini pemahaman kita tentang imajinasi mulai mendekati daerah moral. Pada kenyataannya Inisiatif untuk bertindak tidak pernah langsung dihubungkan dengan kepintaran atau kepandaian intelek. Kepandaian intelek ini yang justru harus didukung oleh imajinasi, sebagai roh agar muncul dalam bentuk kreativitas dan inisiatif bebas manusia.

\section{B. Imajinasi Menghadirkan Realitas}

Berkaitan dengan intelek, ada satu kelebihan imajinasi yang perlu diungkapkan di sini, ialah kemampuannya menghadirkan realitas. Kalau intelek adalah kemampuan untuk mengabstraksi, maka intelek dan imajinasi adalah rangkaian dua kemampuan untuk menghasilkan suatu abstraksi yang real. Ada dua pendekatan untuk menjelaskan hal ini: Pertama, selain menghasilkan gambaran-gambaran mental, imajinasi menghasilkan konsep-konsep imajerial, yakni konsep-konsep yang mengandaikan adanya rangkaian imaji-imaji untuk 
memperjelasnya, dan sebaliknya, konsep-konsep yang hanya dapat muncul dari rangkaian imaji-imaji. Konsep imajerial ini sebetulnya berdekatan dengan konteks imajinasi dalam ilmu-ilmu lain termasuk ilmu seni. Tanpa imaji-imaji penyertanya itu -yang dimunculkan oleh daya imajinasi- konsep-konsep ilmiah menjadi sulit dipahami dan karenanya sulit dibuktikan secara apriori atau mendahului pengalaman. Maka dikatakan bahwa konsep imajerial ini menghadirkan realitas konseptual ilmu-ilmu pengetahuan termasuk ilmu pengetahuan empiris. Konsep imajerial pada dasarnya menuntut kehadiran imaji supaya dapat dikatakan sebagai imajerial. Imajinasi tidak dapat diabaikan atau dipisahkan dari fungsi intelek sendiri yang bertugas mengabstraksi menjadi sebentuk konsep. Pendekatan Kedua adalah pengertian kita terhadap konsep-konsep imajinatif. Konsep-konsep imajinatif sebenarnya bertumbuh dari suatu tahap intelektual yang sifatnya lebih rekonstruktif. Intelek dapat memunculkan atau mensintesiskan suatu ide atau gagasan yang tidak langsung dapat dimengerti meskipun sifatnya sudah sangat logis. Ide atau gagasan dapat menjadi bersifat imajinatif apabila memancing subjek sendiri untuk mengembangkan gagasannya lebih lanjut. Sifat imajinatif itu terdapat pada keterbukaan ke arah pengembangan sebuah gagasan yang dimunculkan oleh intelek. Jadi, suatu konsep dikatakan imajinatif hanya kalau ia memancing subjek untuk mengembangkannya lebih lanjut. Pengertian ini membawa kita pada asalmuasal kreativitas manusia sendiri. Kreativitas berarti kemampuan untuk membuka kemungkinan perkembangan terhadap ide-ide dan gagasan yang lebih statis sifatnya, Artinya, kalau suatu gagasan mulai kita bakukan dalam konsep pemaknaan tertentu, sebenarnya konsep ini tidak pernah berhenti (statis) di situ, karena konsep ini akan berkembang (dinamis) dipicu oleh sifat kreatif imajinasi. Imajinasilah yang membuat konsep-konsep pemikiran itu selalu bersifat terbuka untuk dikembangkan lebih lanjut.

Pengertian imajinasi menghadirkan realitas sebetulnya berkaitan juga dengan kemampuannya membentuk dunia virtual. Menghadirkan realitas berarti memasukkan hukum kausalitas ke dalam alam virtual buatan imajinasi, bersamaan dengan bertumbuhnya kesadaran dan emosi yang menyertainya: Asumsi ini dapat kita pahami dengan melihat kenyataan bahwa apa yang dituju oleh upaya "penghadiran realitas" dalam diri manusia itu tidak pernah merupakan realitas yang konseptual tetapi selalu realitas yang figural. Kita tidak pernah berada dalam sebuah alam konseptual.

Hal ini sebenarnya sudah diimplikasikan dengan istilah "realitas" itu sendiri yang memuat pengertian real. Maka jika kita menghadapi suatu konsep, kita tidak menghadapi suatu entitas yang berdiri sendiri dan real, sejauh konsep itu belum menjadi konsep yang imajerial: Tetapi bila kita menghadapi dan mengalami sendiri suatu dunia atau kondisi yang figural, kita dapat mengatakannya sebagai real karena sifatnya memang dapat dialami. Pembedaan antara yang konseptual dan figural ini telah menjadi salah satu karakter alam pikiran jaman sekarang. Dalam bahasa Scott Lash, keduanya diistilahkan dengan diskursif dan figural. Scott Lash sendiri memakai istilah figural dari Lyotard-untuk membedakan ciri masa modern (yang lebih diskursif) dan postmodern (yang lebih figural) Kesadaran kritis yang paling awal barangkali telah dimunculkan oleh Susan Sontag pada pertengahan tahun 1960-an, ketika ia mengkritik masa modern yang banyak diwarnai oleh estetika interpretasi. Interpretasi menunjukkan isi atau muatan (content) yang memenuhi sebuah karya seni.

Dikatakannya, bahwa masa modern itu telah ditandai dengan kemenangan intelek atas seni yang terwujud dalam istilah interpretasi. Interpretasi adalah sebentuk balas dendam intelek terhadap seni. Lebih lagi, interpretasi adalah balas dendam intelek terhadap dunia, sebab menginterpretasi itu berarti memiskinkan, mengosongkan dunia, untuk membentuk suatu sistem bayangan yang penuh dengan makna (meaning). Implikasi dalam bidang seni ini tentu saja mempengaruhi pemahaman akan imajinasi sebagai daya yang menghadirkan realitas. Realitas yang ditampilkan dalam seni yang penuh muatan makna berarti menandakan kejayaan intelek di atas imajinasi. Justru kebangkitan imajinasi itu dimungkinkan ketika realitas dihadirkan melalui seni yang lebih dingin (cooler art) dan dengan muatan yang lebih sedikit (less content). Dengan demikian, terjadi pula pergeseran dalam bidang seni, dari seni yang bersifat interpretatif ke arah seni yang bersifat lebih sensasional.

Dengan merebaknya kesadaran baru akan realitas yang figural tersebut, kini kita makin dapat mengerti bagaimana imajinasi amat berfungsi dalam membentuk dan menghadirkan realitas. Kesadaran akan kuatnya realitas figural ini -yang akan banyak mendapatkan pendasaran teoretis melalui Lyotard menjadi ciri masa kini yang akan mewarnai pola pikir dan relasi kita dengan dunia, menjadi pintu masuk ke arah dunia imaji-imaji, dunia imajinasi itu sendiri. Dengan ini kita tidak berhenti pada penjelasan kaitan imajinasi dan intelek. Kita justru akan melangkah ke dalam pembahasan proses kreasi yang lebih menyeluruh.

\section{Akselerasi Proses Pengetahuan dan Kreasi Penciptaan Karya seni}

Proses pengetahuan dan proses kreasi dapat digambarkan dalam beberapa pemahaman. Pengetahuan ataupun kreasi adalah pengenalan akan sesuatu dari pengalaman aktual; apa yang dipelajari; persepsi yang jelas (pasti) akan apa yang dipandang sebagai fakta, kebenaran, ataupun kewajiban; hal-hal yang ada dalam kesadaran yang dibenarkan dengan suatu cara tertentu dan dipandang sebagai benar; proses kehidupan yang diketahui manusia secara langsung dari kesadarannya sendiri dengan mengasumsikan pemahaman objek oleh subjek; atau juga dalam arti luas, semua kehadiran intensional objek di dalam subjek. Apabila imajinasi dipaharni sebagai suatu fakultas penyerta (kemampuan yang 
menyertai), maka dimungkinkan kontinyuitas kehadiran dan peran penting daya ini dalam setiap proses pengetahuan dan proses kreasi.

1) Kemampuan Reflektif

Sebagai titik tolak kita ambi! pandangan Kant tentang imajinasi reproduktif. Di dalam daya tersebut, manusia berupaya me-reproduksi kembal gambaran atau imaji yang sudah ada atau sudah pemah dialami sebelumnya secara mental. Kondisi ini mengandaikan suatu pengetahuan yang diperoleh secara aposteriori (dari yang kemudian). Artinya, pengetahuan dipandang terbentuk dari pengalaman. Pengetahuan terbentuk sesudah seseorang mengalaminya sendiri. Dalam kaitan dengan peristiwa, imajinasi reproduktif ini punya kemampuan menghadirkan (representasi). Berbagai imaji dalam diri seseorang yang bersangkutan dengan suatu peristiwa tertentu dihadirkan sebagaimana yang pernah dialami. Akhirnya, peristiwa itu dapat sungguh-sungguh hadir dan seolah dialami kembali pada saat yang lain. Kemampuan imajinasi dalam merepresentasikan suatu peristiwa semacam ini memberi kesempatan kepada kemampuan reflektif kita untuk muncul. Dalam proses penghadiran kembali realitas atau peristiwa itu, kita tidak sekadar menonton film, melainkan melibatkan seluruh emosi dan perasaan yang pernah muncul ketika mengalami peristiwa yang bersangkutan. Lebih lanjut, justru karena masih ada semacam distansi (penjarakan) terhadap peristiwa yan sesungguhnya, kita memunculkan kemampuan reflektif kita, memandang peristiwa tersebut dengan seluruh alur dan emosinya dengan suatu pemahaman kini yang mau tidak mau mengajak kita mengevaluasi kembali pendapat dan kesan kita tentangnya.

Penghadiran kembali suatu peristiwa tertentu pada saat yang lain ini sangat mungkin membawa pemahaman yang berbeda terhadap peristiwa yan sama. Kalau begitu, apa yang kita dapatkan sebagai pemahaman yang berbeda ini termasuk dalam proses pengetahuan. Kita mendapatkan pelajaran dari peristiwa tersebut, dan kini merumuskan kembali suatu sikap dan pendapat yan bersifat lebih pasti. Hasil perumusan kembali ini adalah sebentuk pengetahuan (akan kehidupan) atau ditetapkan sebagai pilihan kreasi.

Proses di atas tidak akan terjadi tanpa adanya daya reproduktif imajinasi. Daya reproduktif inilah yang melahirkan kemampuan reflektif, yang mempercepat proses pengetahuan. Tanpa kemampuan reflektif ini kita akan sulit mendapatkan sesuatu yang berarti dan lebih mendalam dari peristiwa dan pengalaman, yang akan menjadi pengetahuan kita.

Dalam konteks pandangan Kant, pengetahuan dari penghadiran kembali pengalaman secara mental ini selalu berkaitan dengan pengetahuan sebagai hasil kerja sama antara pengalaman indrawi dan keaktifan akal budi (verstand). Namun, harus disadari bahwa tanpa imajinasi proses kerja sama ini mungkin akan berlangsung lebih lama. Dalam hal ini, imajinasi lah yang menyertai setiap gerakan representasional, menumbuhkan imaji-imaji yang semakin lengkap untuk menyerap pemahaman yang baru secara reflektif.

2) Penyerta dalam Membaca

Pengetahuan melekat erat dengan kemampuan membaca (reading) atau memahami bacaan. Tanpa terlalu mudah mengafirmasi suatu penularan pengetahuan atau penularan kebenaran secara sederhana seolah-olah pengetahuan dan kebenaran itu hanya soal kepercayaan terhadap doxa (opini) orang lain- maka tindakan membaca itu mengandaikan suatu transfer pengetahuan. Pengetahuan dipandang sebagai informasi atau pesan yang telah mendapat peneguhan logis maupun empiris dalam diri pembaca. Melalui imagery ini para penyair, penulis. atau pengarang mempergunakan bahasa figuratif guna menghasilkan gambaran dalam pikiran pembaca maupun pendengar. Imajinasi pembaca dipacu dan akhirnya akan memacu pemahaman terhadap informasi atau pesan yang hendak disampaikan oleh penulis/ penyair/ pengarang.

Demikian pula pelukis, pematung dan seniman lainnya kurang lebih sama hanya melalui bahasa rupa. Proses akselerasi pengetahuan terjadi pada saat membaca buku, melihat peristiwa sosial, menafsirkan karya seni, memperhatikan situasi jaman ataupun membaca itu sendiri. Imajinasi bekerja sama dengan akal budi membentuk gambaran (yang bersifat interpretatif) atas apa yang dituliskan/ digubah. Pengertian semacam ini tidak terlalu gampang dipahami dalam konteks pemahaman Derrida tentang tulisan sebagai suatu labirin tekstual yang dikelilingi banyak cermin.

Dalam pandangan terakhir tersebut sebuah tulisan/ gubahan tidak langsung menyampaikan sesuatu, bahkan tidak langsung menyampaikan suatu pengetahuan, melainkan berupa suatu imitasi atas imitasi yang tiada henti. Dalam hal ini, pengetahuan baru ataupun kreasi baru didapatkan bersamaan dengan interaksi subjek (pembicara/ / pelaku) dengan paradigma-paradigma yang melatarbelakangi gubahan-gubahan karya seni/ desain/ tulisan-tulisan itu. Percepatan proses pengetahuan oleh imagery akan lebih mudah dipahami sejalan dengan pandangan Kant sehubungan dengan imajinasi produktif. Berhasil tidaknya penyampaian suatu pengetahuan/ kreasi atau kebenaran oleh seniman/ penulis/ penggubah tergantung sejauh mana pembaca mengaktualisasikan daya imajinatifnya.

Semakin kuat daya imajinatif seseorang, semakin cepat pula suatu teks/ karya seni/ tulisan/ pengetahuan dapat dipahami, atau implikasinya yang lebih jauh, semakin cepat pula proses pengetahuan itu terjadi. Mark dan Esa memberikan deskripsi yang menarik sehubungan dengan daya guna sebuah tulisan. Supaya efektif, tulisan harus menjadi imagoskripsi (imagoscription) yang dimengerti oleh setiap orang. Dalam tulisan ini pula teruji kemampuan imajinatif penyunting menyampaikan realitas tanpa memaksakan suatu interpretasi tertentu. 
Semakin suatu tulisan itu memuat segi-segi yang berimaji (semakin imagoskriptif), maka proses pengetahuan sebagai afirmasi logis maupun empiris atas informasi dan kesan yang disampaikan oleh penyunting akan semakin mudah. Bahasa dan tulisan yang sangat ilmiah dan expert sepertinya tidak selalu menjamin perluasan pengetahuan dan pemahaman. Justru bahasa yang demikian dapat menjadi penjara bagi pengetahuan dan pemahaman, suatu penjara (ketertutupan) bagi relasi intelektual.

\section{E. Penutup}

Dalam konteks siberspasi, yang melanda dunia kini, kecepatan penangkapan informasi menjadi soal nomor satu. Akselerasi proses penerimaan pesan dan informasi pun menjadi sangat krusial dan menentukan. Akibatnya, kecepatan proses membaca suatu informasi atau pesan akan berpengaruh besar pada ketepatan (akurasi) pemahaman dan pengetahuan. Bukan tidak mungkin bahwa pada suatu saat sebuah buku -atau lebih luas, suatu sistem bahasa diskursif-sebagai sumber pengetahuan akan digantikan dengan sebentuk siberspasi. Fenomena ini sudah diramalkan oleh Mark dan Esa,

"Selama beberapa dekade terakhir, para filsuf dan kritikus telah berdebat tentang akhir sejarah dan lembar terakhirnya. Akan tetapi, perdebatan ini lama-kelamaan kehilangan titik pentingnya. Persoalannya bukan sekadar bersifat filosofis atau literal, "tetapi teknologis. Sejarah berakhir dan lembarannya ditutup ketika kontinyuitas naratif terjerumus ke dalam hal-hal yang instan. Kecepatan (speed) adalah penyebab keterjerumusan ini. Mencoba membangkitkan kembali sejarah atau membuka lembaran baru berarti mencoba untuk menginjak rem pada saat kecepatan tinggi telah menjadi millieu kita. "Jika semua pembacaan menjadi pembacaan yang cepat, lantas semua 'buku' mesti berupa textbyte. Tetapi apa artinya melahap sebuah byte ?"

Dalam proses kreasi seni rupa, ujungnya tentu penemuan bentuk-bentuk bahasa ungkap yang mempunyai bobot ungkap tertentu, yaitu bahasa rupa. Akan tetapi perlu juga menjadi catatan bahwa proses kreasi dapat diterapkan pada bidang apa pun, asalkan hasil akhirnya melahirkan karya-karya kreatif. Proses kreasi merupakan perpaduan antara kreativitas personal (imajinasi) dan kreativitas kultural atau manifestasi pribadi sekaligus menyangkut kepentigan budaya. Seperti dijelaskan Semiawan dkk 1988, 61 bahwa:

Pada setiap manusia dapat ditumbuhkan kreativitas personal karena setiap insan memiliki dasar kreativitas tertentu, tetapi kreativitas yang akan memberikan turunan terhadap penemuan-penemuan besa yang membangkitkan kebudayaan atau peningkatan kehidupan manusia secara kualitatif yang disebut kreativitas kebudayaan, adalah pernyataan tertinggi kreativitas manusia.

Pernyataan mengenai kreativitas seni rupa sebagai bagian dari kreativitas kebudayaan menjadi sangat penting, karena setiap perupa adalah insan kebudayaan yang di daiam hidup kesehariannya selalu berurusan dengan kebudayaan sebagai medan/ bahan produksi, permainan yang memberikan ilham-ilham besar. Sebenarnya pemahaman proses kreasi telah dipikirkan dan dicetuskan oleh banyak ahli. Namun secara khusus, persoalan proses kreasi yang langsung berkaitan dengan seni rupa tentunya menjadi pilihan untuk dijadikan referensi langsung.

Seliar apa pun sebuah karya seni rupa, tetap menaruh pengertian orisinalitas (setidaknya dalam artian sebagai gagasan) dan identitas (setidaknya dalam artian relasi pemikiran atau penjelasan yang berkaitan dengan hubungan karya seni dengan penggubahnya). Sebagai simpulan sengaja ditulis tentang usulan-usulan. Pertama, segera dibuat semacam "wadah"(Jw) untuk memberi ruang pada mahasiswa seni rupa (U N Y khususnya) yang berpikir meyamping entah apa namanya seperti New media atau Media alternatif. Kedua, segera disusun tata cara penulisan pameran tugas akhir karya seni (TAKS) baru, antara lain memuat tata tulis yang pada tahapan visualisasi mempergunakan kata "saya", karena "berkarya" sama-sebangun dengan aktualisasi diri, maka dalam konteks ini kata "penulis" menjadi orang lain, kembalikan pada Roh pameran karya studi, bukan seperti pameran seniman.

\section{Daftar Pustaka}

Appleby, Joycee. et. Al. (ed). 1996. Knowledge and Postmodernism in Historical Perspective. New York:Routlege

Baynes.Kenneth.ed..al. (ed). 1991. After Philosophy: End or Transformation?, Massachusetts:The Massachusets Institute of Technology,

Boulding, Kenneth E. 1969. The Image Ann Arbor Papperback.Michigan:The University of Michigan,

Capra, Fritjof. 1977. The Tao of Physics- An Explorration of the Parrallels Between Modern Physics Eastern Mysticism. New York :Bantam,Books,

Coupleston, freederick.S.J 1985. A History of Philosophy- Book Two, consists of Volume iv, V, VI, New York: Image Books- Divison of Doubleday \& company, Inc,

Derrida, Jacques. 1978. Writing and Difference. London:Routledge and Kegan Paul Ltd,

Jencks, Charles (ed), 1992. The Post-Modern Reader. London :Academy Edistions,

Kundera, Milan. 1995. Immortality, Terjemahan oleh Peter Kussi, LondonBoston:Faber and Faber Limited, 
Kearney, Richard. 1994. The Wake of Imagination-Toward a Postmodern culture. London:Rourlege,

Lash, Scott, 1990. Sociology of Postmodernism:London and New York: Routlege, Lechte, John. 1994. Fifty Key Contemporary Thinkers- from Structuralism to Postmodernity. London: Routlege,

Nietzschhe, Friederich. 1968. The Will to Power, terjemahan oleh Walter Kaufmann (ed).New York: Vintage-Books: A division of Tandom House,

Reese, W.L. 1980. Dictionary of Philosophy and Religion Easten and Western Thought. New Jersey: Humanities Press,

Sontag, Susan. 1994. Against Interpretation. London:Vintage,

Semiawan, conny R,.dkk, 1988. Demensi Kreatif dalam Filsafat Ilmu, Remadja Karya CV,Bandung,

Sugiharto, I.Bambang. Postmodernisme: Tantangan bagi Filsafat, Yogyakarta: Kanisius, 1996

Taylors, Mark C. Dan Esa Saarinen, 1994. Imagologies Media Philosopht, London: Routledge, 